\title{
Endovascular correction of a traumatic internal iliac arteriovenous fistula with a covered stent
}

\author{
Correção endovascular de fístula arteriovenosa traumática \\ em ilíaca interna com stent revestido \\ Edson Pedroza dos Santos Junior', Rodolfo Rógers Américo Batista', Fernanda Medina Felici', \\ Vinicius Evaristo Correia', Maykon Brescancin Oliveira', Remy Faria Alves ${ }^{1}$
}

\begin{abstract}
Arteriovenous fistulae (AVFs) are anomalous communications between an artery and a vein, bypassing the capillary network. They can be subdivided on the basis of etiology into congenital and acquired fistulae. The latter may be caused by closed or penetrating traumas, or may be iatrogenic injuries. We report on a case of a young adult female gunshot wound victim treated with emergency laparotomy who developed asymmetrical edema of the lower limbs during the late postoperative period. Imaging exams showed the presence of a left internal iliac AVF, treated using endovascular surgery with placement of a covered stent, resulting in total occlusion of arteriovenous communication.
\end{abstract}

Keywords: traumatic arteriovenous fistula; endovascular surgery; internal iliac artery.

\begin{abstract}
Resumo
As fístulas arteriovenosas (FAVs) são comunicações anômalas entre uma artéria e uma veia, sem envolvimento capilar. Segundo sua etiologia, podem ser divididas em congênitas e adquiridas, resultantes de traumas fechados ou penetrantes, e de lesões iatrogênicas. Relatamos o caso de mulher jovem, vítima de ferimento por arma de fogo, submetida à laparotomia de urgência, que evoluiu no pós-operatório tardio com edema assimétrico de membros inferiores. Os exames de imagem demonstraram a presença de fístula arteriovenosa ilíaca interna esquerda, tratada através de cirurgia endovascular com stent revestido, determinando a total oclusão da comunicação arterial e venosa.
\end{abstract}

Palavras-chave: fístula arteriovenosa traumática; cirurgia endovascular; ilíaca interna. 


\section{INTRODUCTION}

An arteriovenous fistula (AVF) can be defined as an abnormal and permanent communication between an artery and a vein. They may be congenital or acquired, with the latter type being more common. Acquired AVFs are generally the result of a penetrating trauma or injury that lacerates both artery and vein, creating either a direct and immediate connection or an indirect connection via a pseudoaneurysm ${ }^{1,2}$.

The clinical manifestations of an AVF provoke distal and central repercussions and also at the site of the fistula. The most characteristic clinical signs are thrill and murmur, caused by vibration of vessel walls involved by the turbulent flow; it can be observed that the murmur is continuous and with systolic reinforcement. The peripheral manifestations in these cases are weak peripheral pulses, pallor, cyanosis and edema. Some patients exhibit pain and paresthesia of extremities, intermittent claudication and sometimes ulcerations and gangrene. Systemically, heart rhythm, cardiac output, blood volume and ejection fraction can be affected ${ }^{1,2}$.

Diagnosis is confirmed by clinical status and imaging exams, such as vascular Doppler echography and angiography ${ }^{1}$.

Treatment is founded on conventional surgery or angioplasty using therapeutic embolization, covered stents or endoprostheses ${ }^{1}$.

We describe a case of AVF, identified by clinical examination and imaging exams and treated using endovascular surgery. We also present a brief review of the subject in the literature.

\section{CASE REPORT}

A 34-year-old female patient from Nova Olinda, TO, Brazil, was admitted at the emergency department of the Hospital Público de Araguaína (HPA) on 4 January 2009, having suffered a gunshot wound to the left lumbar region, presenting with acute abdomen and hemodynamic instability. She underwent explorative laparotomy and the general surgery team at the hospital sutured vessels and performed segmental enterectomy, enteroanastomosis and enterorraphy on the same day she was admitted. She was transferred to the HPA intensive care unit, where she remained for 2 days before being transferred to the surgical ward. She progressed satisfactorily with hemodynamic stability restored and infection control established.

During the late postoperative period, after 4 months, the patient presented once more, this time with asymmetrical edema of the lower limbs. She was seen by a cardiologist who found edema, more significant on the left, and an abdominal murmur. Computed tomography of the upper and lower abdomen was performed, but failed to find any abnormalities. A duplex scan of the abdominal and pelvic arteries found elevated spectral velocities in the deep vein system and turbulence, suggestive de an AVF in the iliac vessels (Figure 1).

Selective digital subtraction arteriography showed a fistula between the internal iliac artery and vein, close to the origin, with early venous filling and no contrast leaks (Figure 2).

After investigation, the decision was taken to employ endovascular treatment, in view of the location of the AVF close to the pelvic vessels and the difficulties involved in achieving conventional access, including the patient's history of prior abdominal surgery.

The procedure was conducted under local anesthesia by the Hemodynamics Department at the Hospital Privado de Araguína on 7 May 2010 and lasted 1 hour.

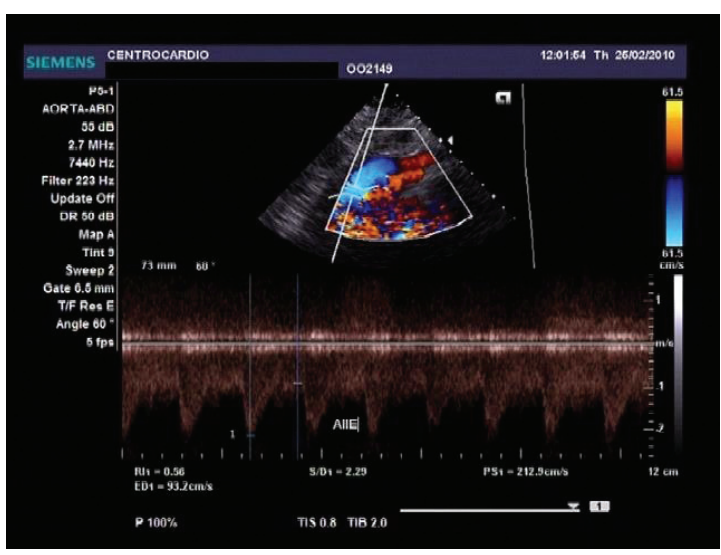

Figure 1. Turbulence between left internal iliac artery and vein.

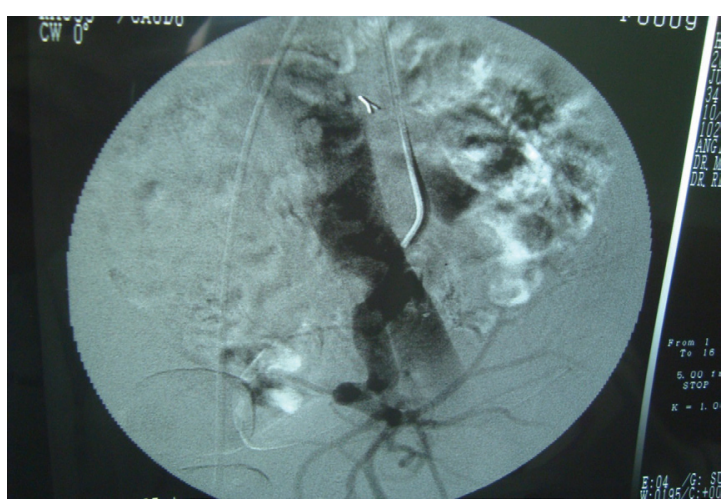

Figure 2. Arteriography demonstrating arteriovenous fistula. 


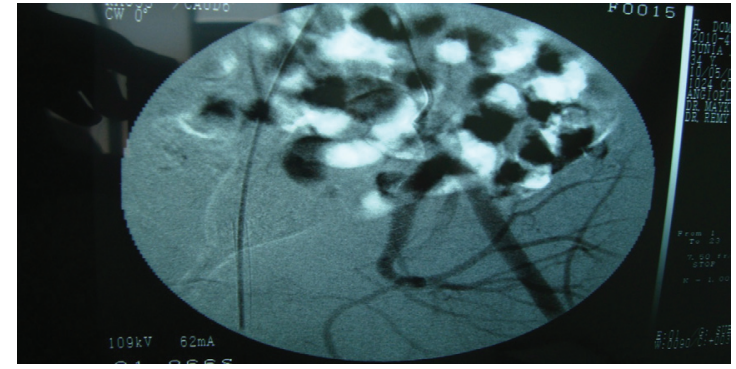

Figure 3. Arteriography after placement of a stent in the left internal iliac artery.

Right femoral puncture was conducted using the Seldinger technique, with insertion of a 5 French (FR) sheath followed by a 0,35 hydrophilic guide wire and a Symon 5 FR diagnostic catheter, with selective catheterization of the left common iliac artery.

The catheter was changed for a Bener 5 FR type and selective catheterization of the left internal iliac artery was performed, before insertion of an Amplatz 0,35 wire, anchored in the left internal iliac artery. It was necessary to change the sheath for a $10 \mathrm{FR}$ to allow passage of a $7 \times 50 \mathrm{~mm}$ Wallgraft Stent, placed so as to cover the entire injury causing the fistula. Postoperative arteriography showed immediately satisfactory results, with no sign of leakage and complete occlusion of the injury. The procedure was conducted with no intercurrent conditions (Figure 3).

Clinical and ultrasonographic follow-up on 4 August 2010, 3 months after the endovascular procedure, showed satisfactory progress without intercurrent conditions and with normal arterial and venous flow restored.

\section{REVIEW OF THE LITERATURE}

\section{Arteriovenous fistula}

An AVF is an abnormal communication between an artery and a vein which does not pass via the capillary network. This abnormal communication between the high-pressure and high-resistance arterial system and the venous system, which has the opposite characteristics, means that the blood flow prefers to pass via the fistula (which has low resistance) rather than via the capillary network ${ }^{1}$.

AVFs can be congenital or acquired and may be single, multiple or associated with other vascular malformations ${ }^{1}$. All types can cause local, regional and systemic effects, depending on size, location and duration of the fistula ${ }^{3}$. The complications vary depending on the size and duration of the resultant shunt ${ }^{1}$.

Acquired fistulae include those caused by traumas, primarily penetrating injuries $(7 \%)^{3}$, and since these involve a high risk of complications, diagnosis should be made and surgical treatment effected as early as possible ${ }^{2}$.

Identification of an AVF during physical examination may be simple, if the characteristic symptoms are present, particularly continuous murmur or palpable thrill, which disappear when the artery feeding the AVF is compressed, while pulsatile bleeding, expansive hematoma and absence of distal pulses may also be observed ${ }^{1,4}$.

Rich et al. ${ }^{5}$ and Stahlke Jr et al. ${ }^{1}$ found that AVFs resulting from trauma are more frequent in the lower limbs, at $30 \%$ and $70 \%$, respectively; in both studies upper limbs accounted for $10 \%$. Robbs et al. ${ }^{6}$ reported on the largest series described in the literature in English, showing that $22 \%$ of 210 traumatic AVFs involved upper limbs and $20 \%$ involved lower limbs.

The longer the interval between injury and repair, the greater the number of complications, and so the concept of waiting for a fistula to 'mature' before initiating treatment should be abandoned. Lack of diagnosis is responsible for AVFs of the limbs becoming chronic, which in turn makes surgical treatment more difficult.

\section{Treatment}

\section{Conventional (open surgery)}

Open surgery for traumatic AVFs should be conducted as early as possible, offering advantages such as better adherence, easier revascularization and lower risk of secondary infections. The objective is to restore blood flow to the region ${ }^{2}$.

In this procedure, venous reconstruction is not essential, since the objective is arterial reconstruction. Notwithstanding, venous repair should be conducted whenever possible using venorrhaphy, primary resection and anastomosis. Ligature of veins should be avoided to prevent edema of limbs ${ }^{1}$.

Successful endovascular treatment has been described by many authors, offering lower surgical risk in difficult-to-access injuries, for which conventional treatment requires large scale surgical exposure that imposes technical difficulties and involves appreciable mortality or morbidity and risk of severe complications ${ }^{7}$.

\section{Endovascular treatment}

\section{Historical aspects}

The initial attempts at endovascular treatment, with endoluminal vascular instrumentation with catheters for therapeutic ends, began during the 
1960s with work by Dotter \& Judkins $(1964)^{8}$. He used balloons positioned in catheters to make the first attempts to deobstruct atherosclerotic stenosis and peripheral arteries 9 .

From the same decade onwards, endovascular diagnosis together with interventional radiology procedures, had made it possible to treat hemorrhages in organs and parts of the body using therapeutic embolization or arterial stenosis using angioplasty ${ }^{10}$. Over the last decade these procedures have undergone an extraordinary rate of development into the arterial tree, in the most diverse range of different vessels, and are now no longer a secondary or exceptional option, but the principal treatment ${ }^{10}$. The first reports of the use of these techniques to close AVFs, especially traumatic AVFs, only appeared recently?.

Treatment includes embolization of fistulae with a variety of agents, such as autologous blood clots; Gelfoam sponges; microfibrillar collagen $\left(\right.$ Avitene $\left.{ }^{\circledR}\right)$; polyvinyl alcohol sponges $\left(\right.$ Ivalon $\left.^{\circledR}\right)$; coils - copolymer covered; detachable and nondetachable balloons, and cyanoacrylate (Brucrylate ${ }^{\circledR}$ ). It is important to point out that treatment with detachable balloons for occlusion of fistulae has become more common than open surgery ${ }^{11}$.

Surgical intervention can very often be complicated, making endovascular treatment of great advantage, particularly since it comprises both a diagnostic and a therapeutic technique, making it very useful in situations such as bleeding; difficult to access sites, such as the thorax and abdomen; for patients with multiple traumas, or for iatrogenic vascular injuries in patients in critical clinical conditions $^{1,7}$.

Use of covered grafts, angioplasty and embolization in endovascular treatments offers specific advantages: the catheter is inserted distant from the injured/diseased area; the procedure is less invasive; there is lower risk of infection; it facilitates access appropriate to the site of injury; it causes less pain and offers better postoperative recovery; it is less expensive, if recovery time and hospital admissions are taken into account; it avoids direct dissection of the surgical field, thereby involving lower risk of nerve damage, and also requires only local or regional anesthesia. However, these treatments are associated with certain risks, including thrombosis of the stent-graft (endoprosthesis), late stenosis and mal-placement ${ }^{12}$.

Open surgery remains of great use for unstable patients, for injuries involving vessels close to joints, such as, for example, popliteal vessels, and for direct surgical repair, which is still preferable to rigid stents. Percutaneous embolization can be the preferred treatment for small and peripheral AVFs, and also for difficult sites ${ }^{1,4}$.

\section{CONCLUSIONS}

Collaboration between vascular surgery and intervention with imaging procedures was fundamental to choosing the most appropriate technique for the case. Endovascular treatment was chosen because of the difficulty of conventional access to the pelvic vessels, aggravated by the prior abdominal surgery. Other factors taken into consideration were reduced risk of infections, insertion of the catheter distant from the injured/ diseased area, reduced pain and better postoperative recovery.

The successful results of this surgery bear out what the literature has been describing over the years with relation to endovascular procedures.

\section{REFERENCES}

1. Stahlke Júnior HJ, Colpo PG, Jacobovicz C, Stahlke PH, Souza DF, Araújo WJB. Fístulas arteriovenosas traumáticas tardias: Revisão de 154 casos operados. Rev Angiol Cir Vasc. 2005;5:223-30.

2. Erkut B, Karapolat S, Kaygin MA, Unlü Y. Surgical treatment of post-traumatic pseudoaneurysm and arteriovenous fistula due to gunshot injury. Ulus Travma Acil Cerrahi Derg. 2007;13(3):248-50. PMid:17978904

3. Baril DT, Denoya PI, Ellozy SH, Carroccio A, Marin ML. Endovascular repair of a traumatic arteriovenous fistula 34 years after the injury: report of a case. Surg Today. 2007;37:78-81. PMid:17186353. http://dx.doi.org/10.1007/s00595-006-3323-5

4. Reyes MO, Escalona DG, Arias OD, Aguilera MVG. Fístula arteriovenosa postraumática. A propósito de un caso. MediSur. 2010;8(2):71-4.

5. Rich NM, Hobson RW, Collins JG. Traumatic arteriovenous fistula and false aneurysms: A review of 558 lesions. Surgery. 1975;78:81728. PMid:1188624.

6. Robbs JV, Carrim AA, Kadwa AM, Mars M. Traumatic arteriovenous fistula: Experience with 202 patients. Br J Surg. 1994;81(9):1296-9. PMid:7953391. http://dx.doi.org/10.1002/bjs.1800810912

7. Fernandes e Fernandes R, Pedro LM, Evangelista A, et al. Tratamento endovascular de lesões arteriais traumáticas. Angiol Cir Vasc. 2011;7(1)

8. Dotter CT, Judkins MP. Transluminal treatment of arteriosclerotic obstructions: description of a new technique and a preliminary report of its application. Circulation. 1964;30:654-70. http:// dx.doi.org/10.1161/01.CIR.30.5.654

9. Shirakawa M, Nishioka T, Yamashita K, Maeda Y, Arita N. Traumatic Vertebro-vertebral Arteriovenous Fistula Manifesting as Radiculopathy. Neurol Med Chir (Tokyo). 2008;48:167-70. http://dx.doi.org/10.2176/nmc.48.167

10. Ramacciotti E, Gerardi Filho VA, Fagundes DJ. Tratamento endovascular de fístulas arteriovenosas. Acta Cir Bras. 1999;14(1).

11. Yared K, Baggish AL, Wood MJ. High-output heart failure resulting from a remote traumatic arteriovenous fistula. Can J Cardiol. 2009;25(4). http://dx.doi.org/10.1016/S0828-282X(09)70083-2

12. Reddy M, Schöggl A, Saringer W, Reddy B, Matula C. Traumatic Arteriovenous Fistula of the Vertebral Artery - Case Report. Neurol Med Chir (Tokyo). 2002;42:289-92. http://dx.doi. org/10.2176/nmc.42.289 
Correspondence Edson Pedroza dos Santos Junior Av. Alfredo Nascer, 828 - Centro Paraíso do Tocantins (TO), Brazil E-mail: epedrozaj@@hotmail.com

Author's information

EPS) é Médico graduado pelo Instituto Presidente Antônio Carlos (ITPAC), Araguaína, TO, Brazil RRAMB é Médico graduado pelo Instituto Presidente Antônio Carlos (ITPAC), Araguaína, TO, Brazil FMF é Médica graduada pelo Instituto Presidente Antônio Carlos (ITPAC), Araguaína, TO, Brazil

VEC é Médico graduado pelo Instituto Presidente Antônio Carlos (ITPAC), Araguaína, TO, Brazil MBO é Médico Cirurgião Vascular, Chefe do Serviço de Cirurgia Vascular, Professor da Disciplina de Clínica Cirúrgica do Instituto Presidente Antônio Carlos (ITPAC), Araguaína, TO, Brazil RFA é Médico Cirurgião Vascular, Chefe do Serviço de Cirurgia Vascular, Professor da Disciplina de Clínica Cirúrgica do Instituto Presidente Antônio Carlos (ITPAC), Araguaína, TO, Brazil

Author's contributions Conception and design: FMF, VEC, EPSJ, RRAMB Analysis and interpretation: MBO, RFA

Data collection: FMF, VEC, EPSJ, RRAMB Writing the article: EPSJ, RRAMB, FMF, VEC Critical revision of the article: MBO, RFA, RRAMB, EPS) Final approval of the article*: RRAMB, EPSJ, MBO, RFA, FMF, VEC Statistical analysis: N/A

Overall responsibility: MBO, RFA Financial support: None

*All authors have read and approved of the final version of the article submitted to J Vasc Bras. 